\title{
現代日本の別荘における海に臨む室の眺望と通風 UTILIZATION OF SEAWARD VIEWS AND CROSS VENTILATION IN CONTEMPORARY JAPANESE VILLAS
}

\author{
藤原紀沙*, 佐藤芙紀 ${ }^{*}$, 村田 涼***, 湯 淺和 博 ${ }^{* * *}$, 安田幸一 $* * * * *$ \\ Kisa FUJIWARA, Fuki SATO, Ryo MURATA, \\ Kazuhiro YUASA and Koichi YASUDA
}

\begin{abstract}
This study aims to clarify how to utilize seaward views and cross ventilation in contemporary Japanese seaside villas, focusing on morphological characteristics of the windows. The present study has demonstrated twelve patterns of the utilization of seaward views and cross ventilation in contemporary Japanese seaside villas. Furthermore, we clarified the characteristics of the window compositions by arranging the patterns from the directivity to the sea: on the basis of cross ventilation following the sea breeze, window constitution with views limited to the sea and window constitution with expanding views around the sea are often found.
\end{abstract}

Keywords: Villa, Sea, Window, View, Cross Ventilation, Composition 別荘, 海, 空, 眺望, 通風, 構成

\section{1. 序論}

\section{1 研究の背景と目的}

屋外の環境に対応した快適な住環境の実現は、住宅設計における 普遍的なテーマであり、地域の気候や地理的な特性を生かした様々 な工夫が行われてきた。特に自然豊かな景勝地に建つことが多い別 荘には、屋外環境に開かれた自然を楽しむ住まい注1) としての特徵 が顕著である。これらの別荘では都市部とは大きく異なる豊かな環 境に対していかに開くかということが重要な設計課題となっており、 それぞれの立地条件に応じて建物と周囲の環境との関係が考察され、 特に開口部において様々な実践がみられる。

特に海に臨む別荘では、水平線を臨む雄大な眺めや心地よい波 風といったように海に対していかに構えるのかが主題となり、海建物一陸という空間軸の中での開口部のあり方が重要になると考え られる。しかし、海から吹く風は季節や天候によっては強すぎるこ ともあり、広く眺望を得るための海側の空をそのまま開放すること が難しい場合もある。そのため、海に対する眺望と通風の組合せは、 海側と陸側という位置関係も加味した開放のあり方として捉えられ る。つまりその特徵は、例えば、海に面した大きな空を開閉部分と
はめ殺し部分によって構成し、ひとつの大開口に景色と風の両方を 採り込む役割を重祮合わせるものや、海に対しては眺めを、陸に対 しては風通しをというように空の役割を場所ごとに使い分けるもの など、眺望と通風という性質の異なる開放性を担う空の構成に顕著 に表われると考えられる。そして、このように海に臨む別荘におけ る眺望と通風という異なる開放性のバランスに着目することで、景 勝地という特徵的な環境条件に適応した住まいの開放性の特徵の一 端を明らかにすることができると考えられる。

そこで本研究では、現代日本の別荘注2)における海に臨む室注3) を対象に、海に面する大開口の配置や風を取込むための空の開閉部 分の組合せなどの形態的な特徵を通して、空を主体とした空間の構 成に表われる眺望と通風の関係性を明らかにすることを目的とする。

\section{2 既往の研究}

これまでになされてきた戸建住宅に関する学術的な研究の内、地 域の環境特性に応じた住宅のあり方を検討したものには、北海道の 寒冷な気候や沖縄の高温多湿な気候に対応した住宅の空間構成やそ の変遷を明らかにしたもの ${ }^{3)}{ }^{4)}$ がある。

建築空間の構成や形状とその室内環境との関係性を明らかにした

\footnotetext{
本論文は 2015 年度日本建築学会大会学術講演会(関東)で発表したものを修正してまとめたものである。

** 元東京工業大学大学院理工学研究科建築学専攻 大学院生・修士(工学)

*** 東京工業大学大学院理工学研究科建築学専攻 准教授・博士(工学)

**** 東京工業大学大学院理工学研究科建築学専攻 准教授.工博

Grad. Stud., Tokyo Institute of Technology, M.Eng.

Former Grad. Stud., Tokyo Institute of Technology, M.Eng.

Assoc. Prof., Dept. of Architecture, Tokyo Institute of Technology, Dr.Eng.

Assoc. Prof., Dept. of Architecture, Tokyo Institute of Technology, Dr.Eng.

Prof., Dept. of Architecture, Tokyo Institute of Technology, Ph.D.
} 
ものには、著者らによる寒冷な地域の住宅における形状と断熱性能

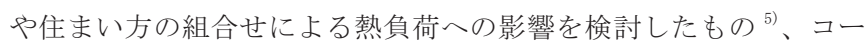
トハウスを対象に空間構成と光環境の特徵の関係性を体系的に比較 したもの ${ }^{6)}$ の他、ロッジア的空間をもつ住宅作品を対象に空間的 性格を日照や配置などから検討したもの ${ }^{7)}$ 、多数の建築実例を対象 に空間特性を考慮した採光方式を体系化したもの ${ }^{8)}$ が挙げられる。

また、建物の形式などの空間的な特徵と通風の性状を定量的に検 討したものには、実測や風洞実験などを通じて住宅の通風量や気流 速度、室温などの実態を明らかにしたもの ${ }^{9)}{ }^{10)}{ }^{11}$ 、通風性能の評 価法や通風量の予測法を提案するもの ${ }^{12)}$ 13) 14) がある。

これらは住宅の空間的な特徵を通風や地域性といった環境の特性 との関係から検討する上で、いずれも重要な視座を提供している。 これらの既往研究に対し、海に臨むという特徵的な環境に立地する 現代日本の住宅作品に着目し、空の配置や開閉の組合せといった形 態的な特性から、眺望と通風という異なる水準の開放のバランスに よる屋外に開かれた住まいのあり方を検討した既往研究はみられな い。そのため、本研究の成果は地域の特性を活かした住宅の計画手 法に関して有用な知見を与えるものと考える。

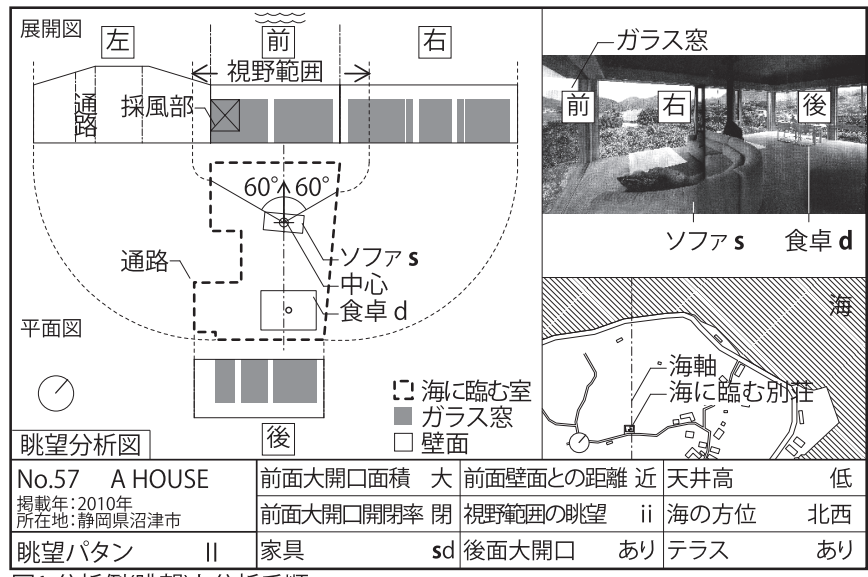

図1 分析例(眺望)と分析手順

表1 大開口の配置からみた眺望パタン

\begin{tabular}{|c|c|c|}
\hline 前+2面 (17) & 前+1面 (24) & 前のみ (24) \\
\hline 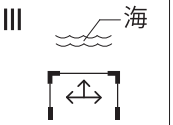 & $\begin{array}{l}\text { II } \approx \\
\qquad \uparrow\rceil\end{array}$ & I $\approx$ \\
\hline
\end{tabular}

\section{表2前面の大開口の面積}

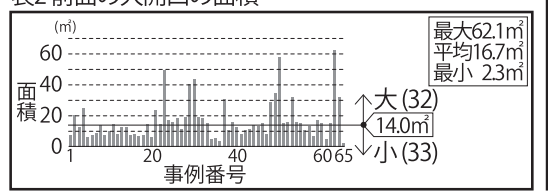

表3 前面の大開口の開閉率

\section{表4 家具による居場所の数と種類}

\begin{tabular}{|c|c|c|c|}
\hline \multirow{2}{*}{\multicolumn{3}{|c|}{ 家具あり(60) }} & 家具なし \\
\hline & & 複数 $\quad$ (38) & \multirow{3}{*}{$9 \quad$ (5) } \\
\hline ソファ & 食卓 & $1-$ - $^{-1}$ & \\
\hline 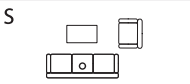 & d 响回 & 品 & \\
\hline
\end{tabular}

表5 居場所と前面壁面の距離

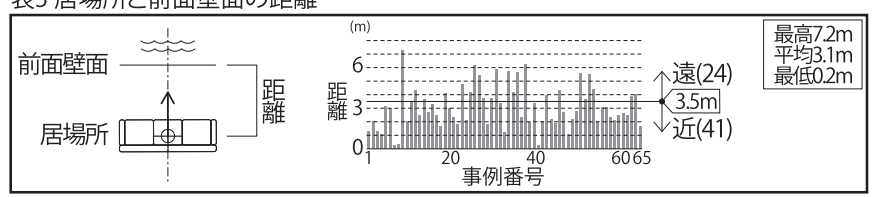

\section{3 研究の方法と概要}

序章に続き、 2 章では、空や家具の配置といった諸要素の形態及 びそれらの組合せに着目し、眺望に関係する構成的な特徽について 検討を行う。まず、海に臨む室における大開口の配置から眺望パタ ンに分類する。併せて、海に面する大開口の面積、これらの大開口 のうち採風可能な部分の割合について検討する。次に、家具によっ てしつらえられた場所について、その数と種類、海に面する大開口 との距離、視野範囲における眺望を検討寸る。それらをふまえ、大 開口の配置による眺望パタンの性格を考察する。

3 章では、開閉可能な空の位置関倸といった領域的な特徵から、 通風に関係する構成的な特徴について検討を行う。そこで、採風可 能な窓の配置を立体的に捉え、これらを海との位置関係を基準に通 風パタンに分類する。次に、このような通風の経路の領域的な特徵 を室や家具との関係から検討する。

4 章では、前章までをふまえ、眺望パタンと通風パタンを組み合 わせて検討し、海に臨む室の空の構成に表われる開放性の特徵から 眺望と通風の関係性について考察する。さらに、得られた開放パタ ンを海への指向性という指標から整理し、海に臨む別荘における空 の構成に内在する眺望と通風のバランスについて考察する。

表6 居場所からの視野範囲における眺望
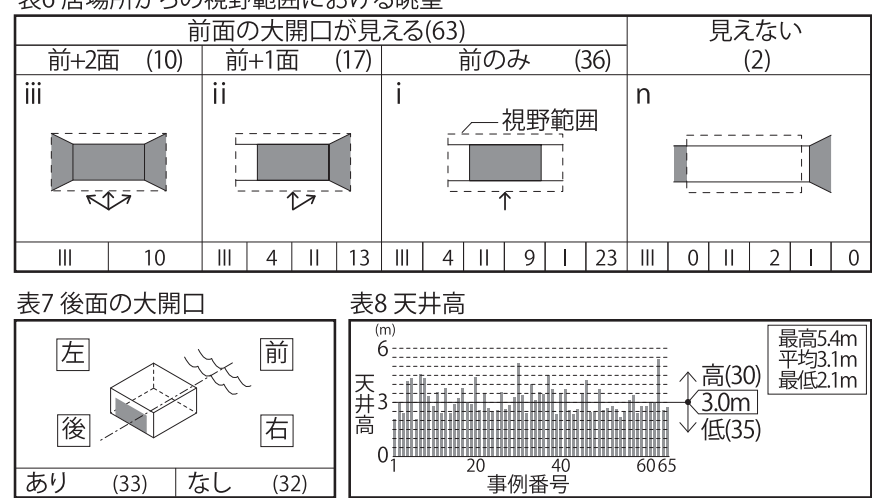

表 8 天井高

表9海の方位

西( 6)
南西( 6)
南東(13)
東(10)

表10 隣接するテラスの有無

\begin{tabular}{|c|c|c|}
\hline \multicolumn{2}{|c|}{ テラスあり } & テラス \\
\hline 前 (55) & その他 (2) & なし \\
\hline$\approx \approx$ テテラス & $\approx \widetilde{テ テ ス}$ & $\approx \approx$ \\
\hline 7 & $T \quad 7$ & 7 \\
\hline 1 & II & 1 \\
\hline
\end{tabular}

表11 眺望パタンの性格

\begin{tabular}{|c|c|c|c|c|c|c|c|c|c|c|c|c|c|c|}
\hline \multicolumn{2}{|c|}{ 眺望パタン } & \multicolumn{2}{|c|}{\begin{tabular}{|l|l|} 
前面 \\
開閉率
\end{tabular}} & \multicolumn{2}{|c|}{\begin{tabular}{|l|} 
面積 \\
$大$ 小
\end{tabular}} & \multicolumn{2}{|c|}{$\begin{array}{l}\text { 距離 } \\
\text { 近近 }\end{array}$} & \multicolumn{3}{|c|}{ 後面 } & $\begin{array}{l}\text { 天井高 } \\
\text { 高 低 }\end{array}$ & 海の方位 & \multicolumn{2}{|c|}{\begin{tabular}{|l|} 
テラス \\
ありなし
\end{tabular}} \\
\hline \multirow{2}{*}{$\begin{array}{l}\text { 前 } \\
\text { IIII } \\
\text { (17) } \\
\frac{1}{\text { 面 }}\end{array}$} & \multirow{2}{*}{$\approx \stackrel{\approx}{\leftrightarrow}$} & 閉 & 7 & 3 & 4 & 1 & $6 \quad \begin{array}{l}i \\
i \\
i \\
n\end{array}$ & & & 3 & 2 & 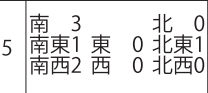 & \begin{tabular}{l|l}
0 & \\
0 & 7
\end{tabular} & 0 \\
\hline & & 園 & 10 & 5 & 5 & 5 & 5 iii & & & 7 & 4 & 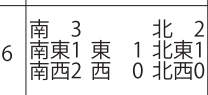 & $\begin{array}{ll}1 & 7 \\
0 & 7\end{array}$ & 3 \\
\hline \multirow{2}{*}{$\begin{array}{l}\text { 前 } \\
\text { II } \\
\text { (24) } \\
1 \\
\text { 面 }\end{array}$} & \multirow{2}{*}{$\approx \uparrow$} & 閉 & 10 & 3 & 7 & 0 & 10 iii & & 4 & 6 & 2 & 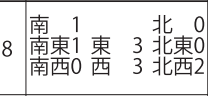 & \begin{tabular}{l|l}
0 \\
0 & 9
\end{tabular} & 1 \\
\hline & & 園 & 14 & 6 & 8 & 5 & $9{ }_{i}^{i i}$ & & & 6 & 5 & 9 南央束4 東 2 北東 21 & 10 & 0 \\
\hline \multirow{2}{*}{$\begin{array}{l}\text { I } \\
\text { (24) } \\
\text { (前 } \\
\text { み }\end{array}$} & \multirow{2}{*}{$\approx \approx$} & 開 & 10 & 3 & 7 & 6 & $\left.4\right|_{i} ^{i i}$ & & & 2 & 8 & 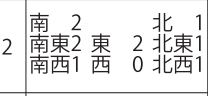 & 7 & 3 \\
\hline & & 定 & & 10 & 4 & 6 & $8 i_{i}^{i}$ & & & & 9 & 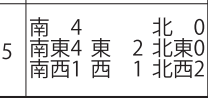 & \begin{tabular}{l|l|l}
0 & 0 \\
0 & 13 \\
\end{tabular} & 1 \\
\hline
\end{tabular}

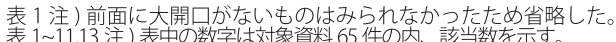




\section{2. 大開口の配置と眺望}

\section{1 大開口の配置}

まず、海に臨む室における空の配置を検討する（図 1)。海に最 も近い壁面を前面とし、その左右を含めた壁面の大開口注4) の配 置を眺望パタンとして分類した（表 1)。前面には全ての事例にお いて大開口があり、海に近接するように眺望を得るための大きな 空を設ける形式が基本にあることがわかる。また、前面のみの I (24/65)、前面に加え左右いずれかの II $(24 / 65)$ のように、大開口 による眺望に方向の偏りがあるものが多く、海一の眺望を前面に限 定するだけでなく、パノラマ状に広げる形式も同様に多いことがわ かる。このような海への眺望の大きさを前面の大開口の面積から検

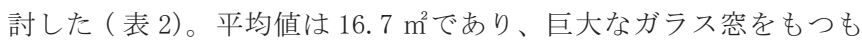
のが多いことがわかる。さらに、これら前面の大開口における、眺 望と採風という空の役割の複合を捉えるため、採風可能な部分（以 下、採風部）の前面の大開口に占める面積の割合（以下、開閉率） を検討した（表 3)。採風部の割合が $50 \%$ 未満のものが過半数を占 め $(38 / 65)$ 、総じて眺望優先の大開口が多いが、 $20 \%$ 台と $90 \%$ 以上 に事例数が集中しており、海に面寸る大開口は採風部が小さいはめ 殺し主体の空と、ほぼ全面が開閉可能な空というふたつが主流であ ることがわかる。

\section{2 居場所と眺望の関係}

次に、家具によってしつらえられた人が座る場所（以下、居場 所）と空の関係から海への眺望について検討する。まず、居場所の 数と種類を家具注 5 ) をもとに検討した (表 4)。大半が複数 $(38 / 65)$ の家具を配置するもので、くつろぐための腰掛具が主体のもの（以 下、ソファ) や食事などを行なう机が主体のもの（以下、食卓）と いう性格が異なる居場所を併置する傾向がある。さらに、居場所と 前面の壁面との距離注 6 ) を検討した (表 5$) 。 3.5 \mathrm{~m}$ 注7) 未満が過半数 を占め、前面の壁面の近傍に居場所をしつらえるものが多い。ま た、居場所からの視野範囲注 ${ }^{8)}$ における海への眺望を、大開口の配 置から検討した（表 6)。前面の空のみから海が見える i が最も多 く(36/65)、次に前面と他の 1 面から見える ii $(17 / 65)$ が多い。こ れらを大開口の配置と併せて検討寸ると、ii と II 、 i と I という見 え方と大開口の配置が一致するものが多いが、 i と IIIや II 、 ii と III のように、大開口の配置に対して海が見える範囲が限定されるもの もみられた $(17 / 65)$ 。

\section{3 眺望パタンの性格}

前節の居場所との関係に加え、海と反対側への眺望を後面の大 開口の有無（表 7）から、垂直方向の広がりを天井高注9) (表 8) から、 海の方位との対応を前面が面する方位（表 9) から、隣接する屋外 空間との関係をテラス ${ }^{\text {ì 10) }}$ の有無（表 10）から捉え、眺望パタンの 性格を考察する (表 11)。前面の大開口の開閉率、面積ともに眺望 パタンによる該当事例数の偏りは少ないが、Iには開閉率が低いも のでは面積が大きいものが多く、単一方向への眺望を主体とするも のは空が大きい傾向が伺える。居場所と前面の壁面との距離をみる と、III、II では近いものが多いのに対し、I では近いものと遠いも のがほぼ同数あり、特に I と開閉の組合せでのみ遠が近より多くみ られた。後面の大開口をみると、パタンごとの偏りは少ないが、I の後面の大開口有りのように、海に対する軸性を強める大開口の 配置が 2 割みられ（13/65）、IIIの後面の大開口有りのように四方に
大開口をもち、眺望の特徵が顕著なものは約 1 割みられた $(10 / 65)$ また、天井高は開閉率によらず、III と II では低、I では高が多い。 天井高の低いものは複数面に大開口を配置することで水平方向の広 がりをつくり、天井の高いものは大開口を前面のみに制限するこ とで垂直方向の広がりをつくる傾向があるといえる。海の方位は III、I は南が多く、II では東西方向に偏りがみられた。また、室に 隣接するテラスは多くの事例でみられた $(57 / 65)$ 。その大半が室の 前面に位置し (55/57)、それ以外のものも室の左右に位置し $(2 / 57) 、$ 海軸への眺望が得や寸い配置である。

\section{3. 採風部の組合せからみた通風 \\ 3.1 採風部の組合せによる通風経路}

通風の性状は外部環境、周辺の状況や建物の特性に影響され、そ の効果を設計者が個別に定量的に評価しながら設計することは容易 ではない。また、通風経路の検討は開口の形状、位置、大きさなど の配置によって大きく影響される注11) ため、定性的に行われること が多い。そこで、本章では空の組合せを主とした構成的な特徵に着 目し、通風の性状について検討する。

まず、海に臨む室において通路や吹抜けによって空気がつながる 範囲（以下、採風範囲）を設定し採風部の位置関係を検討する。次 に、異なる壁面に設けられた空の採風部の中心どうしを結んだ線を 通風経路の軸とした（図 2)。そして、前面壁面に直交する軸（以下 海軸）を基準として、海軸に沿う経路で風を採り込む海軸経路、海 軸に沿わない経路の他軸経路に分類し、それらの組合せを通風パタ ンとして 4 つに分類した（表 12）。通風経路の軸をつくるA、B、C が 大半であり $(60 / 65) 、$ 採風部が 1 面だけで通風経路の軸をつくらな いD は少ない $(5 / 65)$ 。また、通風経路の軸があるものは、海軸経路 と他軸経路の両方がある A、海軸経路のみの B が大半を占め $(47 / 65)$ 海からの風向きに沿って風を採り込む経路をつくるものが多いとい える。さらに、屋根面に設けられた天密について併せて検討したと ころ、約 3 割（17/65）の事例で天空が設けられていた。その内、開 閉可能なもの（以下、採風天空）は約 1 割 $(7 / 65)$ と少なく、また通 風経路の軸がないDにはみられなかった。このことから、通風は壁 面に設けた空の組合せによって確保する傾向があるといえる。次に、 通風経路の軸がある $A 、 B 、 C(60 / 65)$ について、各経路を海風に対し て風上にあたる前面の空を通る経路と、通らない経路に分類し、そ の組合せを検討した（表 13）。ほぼ全ての事例が前面の空を通る経路 をもち (59/60)、前面のみのものと前面以外の経路をもつものはほぼ 同数みられた。

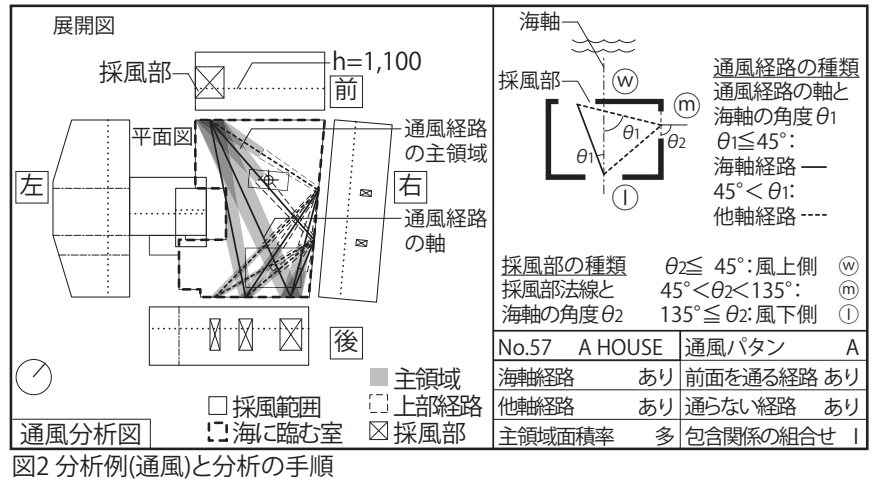


表12 空同士の関係からみた通風パタン

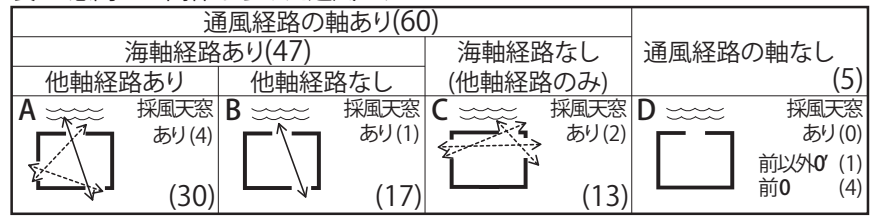

表13 通風経路の軸の種類 表14 通風経路の主領域の面積率

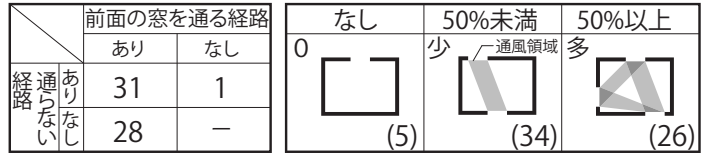

表15 通風経路の主領域の居場所との包含関係とその組合せ
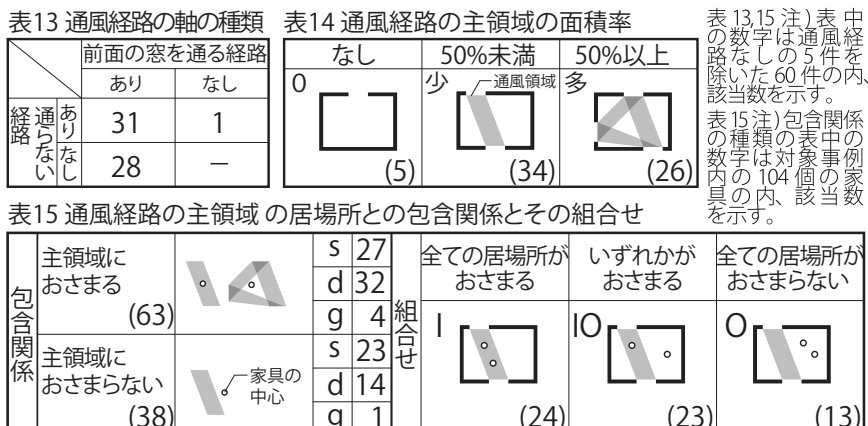

(38)

\begin{tabular}{l|l|l}
\hline $\mathrm{g}$ & 1 \\
\hline
\end{tabular}

(24)

(23)

(13)

表16 通風パタンの領域的性格

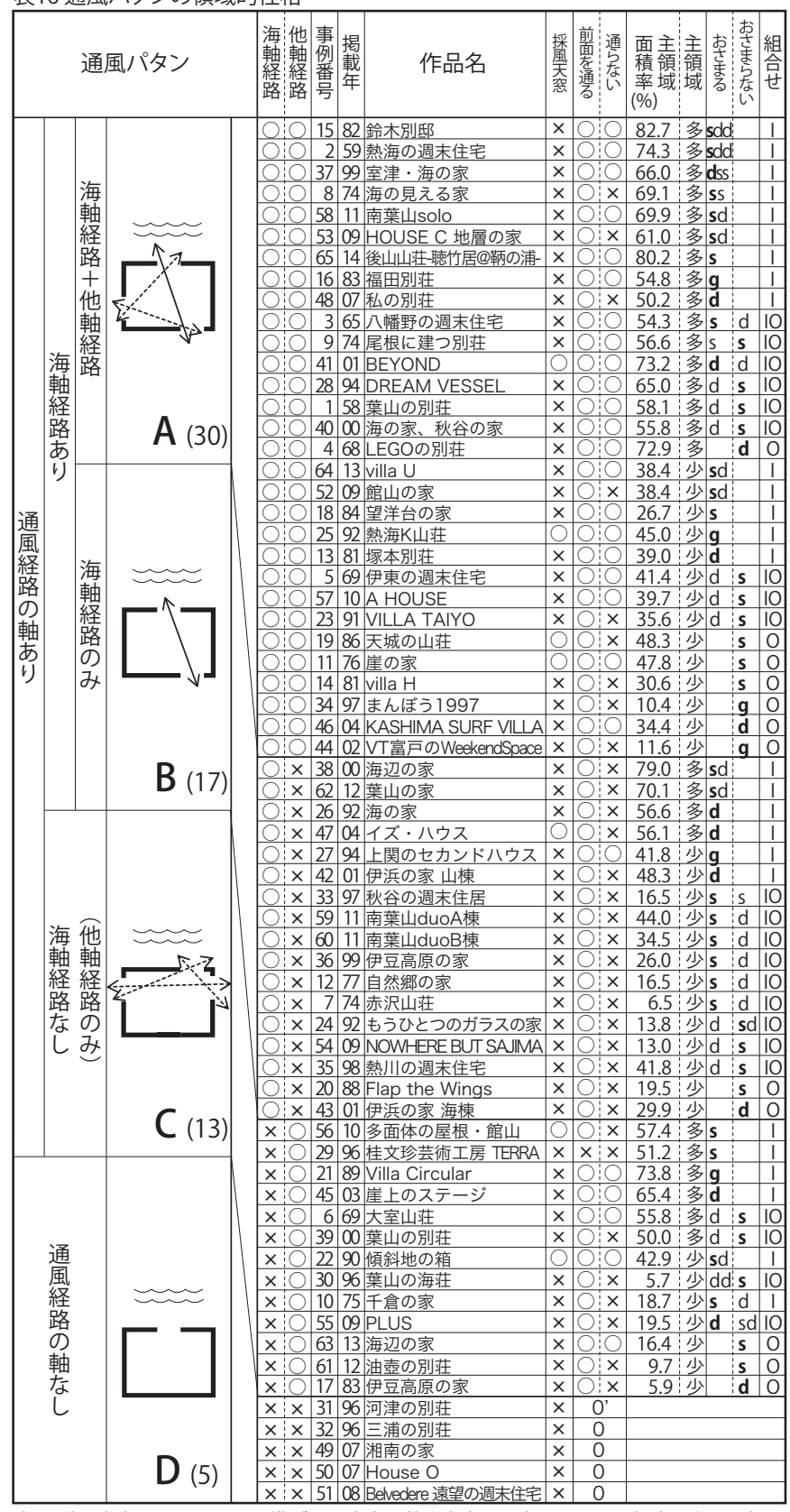

表16 注) 表中記号は4 4 15 に準ずる。太字の英小文字は、表 7 において視点となる居場所

\section{2 通風経路の領域的特徵}

さらに、室内での通風経路について、採風部の輪郭どうしを結ん だ立体的な領域を通風経路の主領域とし、その空間的な特徵を捉え るため、床から $1,100 \mathrm{~mm}$ の高さの平面における室の床面積に占める 割合を検討した ${ }^{12}$ ( 表 14)。50\%未満のものが大半を占め $(39 / 65)$ 、 通風経路の主領域が室全体に広がるものよりも、局所的な範囲に限 定されるものが多い。また、通風経路の主領域における居場所の包 含関係を検討すると（表 15）、これらの領域におさまるものは食卓 が最も多い $(32 / 63)$ 。それらの組合せをみると、全てもしくはいずれ かがおさまるものが大半である $(47 / 65) 。$

\section{3 通風パタンの領域的性格}

通風経路の主領域の面積率や居場所との包含関係から、通風パタ ンの領域的性格を考察する（表 16）。通風領域の面積率に着目する と、A、Cでは偏りが少なく、B では低いものが多くみられた $(13 / 17)$ このことから、他軸経路があるものは通風経路の主領域が様々な広 がりをもつのに対し、海軸経路のみのものは領域が局所的なものが 多いといえる。また、通風経路の主領域と居場所の種類に着目寸る と、特に B は複数の居場所のいずれかがおさまることが多く、その 領域との位置関係によって、居場所の性格が分かれているといえる。

\section{4. 眺望と通風の関係性からみた海への指向性 \\ 4.1 眺望と通風の関係性からみた開放パタン}

前章までの眺望パタンと通風パタンの関係性を検討し、海に臨 む室における眺望と通風という性質の異なる開放性の組合せとし て、12 種の開放パタンを得た（表 17）。このうち、(1)(2)(3)は海側の 3 面全てに大開口があり、海への方向に加え他の 2 方向に広がる眺 望をもつものである。(1)海軸経路と他軸経路の両方があり、全方 向的な眺望に多様な通風経路が同調し、屋外一の開放性を強めるも のである。該当する事例数が最も多く、その中でも前面の大開口は 開閉率が低いものが多く、眺望を優先する空とする傾向が強い。ま た、開閉率が高いものには居場所と前面の壁面との距離が近いもの が多く、屋外一広がる眺望と海からの通風の両方を得る居場所が海 を臨む空に近い傾向が伺える。(2)は海軸経路のみがあるもので、全 方向的な眺望に対して海軸に沿う通風が、海への方向性を強めるも のである。前面の大開口の開閉率が高いもののみに、該当する事例 がみられた。(3)は他軸経路のみがあるもので、通風には海への方向 性がなく、眺望による全方向的な屋外への広がりが際立つものであ る。なお、これらの眺望パタンには通風経路の軸がない事例はみら れなかった。(5)(6)(7) (8)前面に加え左右いずれかの面に大開口があ り、海への方向に加え他の 1 方向に眺望が広がるもので、大開口の 方位は、(5)東側、(6)西側が多く、眺望の方向性の広がりの偏 りが、朝日や夕日といった特徵的な日光との対応を示すものが多 い。(5)は海軸と他軸の両方の経路によって海風を採り込み、眺望の 偏りと通風の多様さが組み合わされるものである。前面の大開口は 開閉率が低いものが多く、眺望を優先する空とする傾向が強い。(6) は 2 方向に広がる眺望に対して、通風は海軸のみの経路として海一 の方向性を強めるものである。通風経路の主領域の面積率が低いも のが多く、海への方向性の強い場所が局所的な海風によって生じて いる。(7)は他軸経路のみで、通風には海への方向性がないものであ る。(8)通風経路の軸がないもので、前面のみに採風部があり、開 
表17 眺望と通風の関係性からみた開放パタン

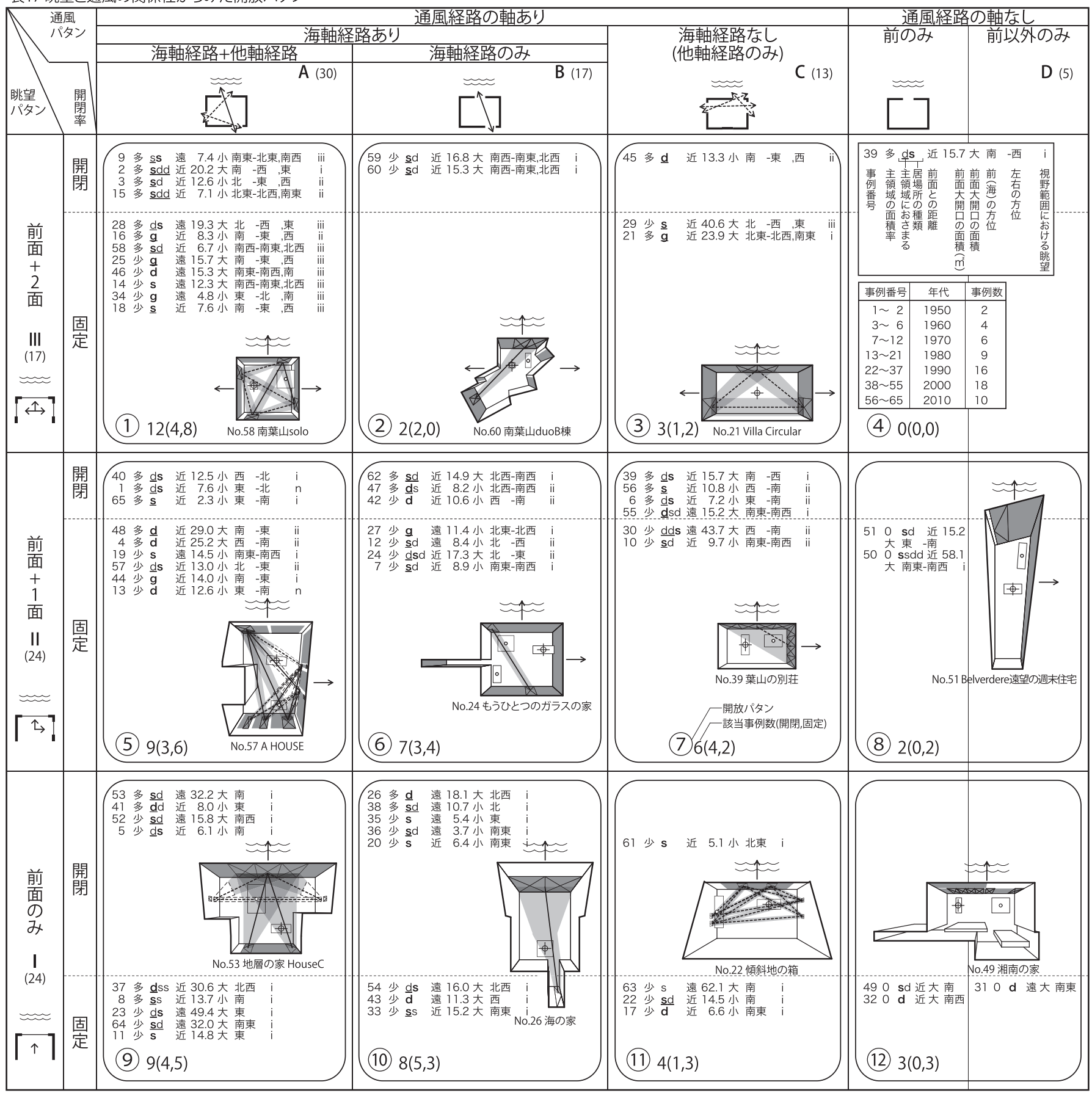

閉率が低いもののみに該当する事例がみられた。(9)(10)(11)(12)前面の みに大開口があるもので、眺望による海への方向性が強いものであ る。99海軸之他軸の両方の通風経路の軸があり、眺望による海へ の方向性に対して、通風が屋外への広がりを加えているものである。 (10は眺望と通風のいずれも、海への方向性をもつものである。通風 経路の主領域の面積率が低いものが多く、局所的な海からの風が特 徵的なものである。居場所と前面壁面の距離が遠いものが特に多く みられ、海から離れた位置に居場所をしつらえるものが多いといえ る。(111は他軸のみに沿う通風経路があり、(12)には通風経路の軸がな く、いずれも眺望による海との関係が際立つものである。ともに開 閉率が低いもののみに該当する事例がみられ、特に眺望を優先する 傾向が伺える。

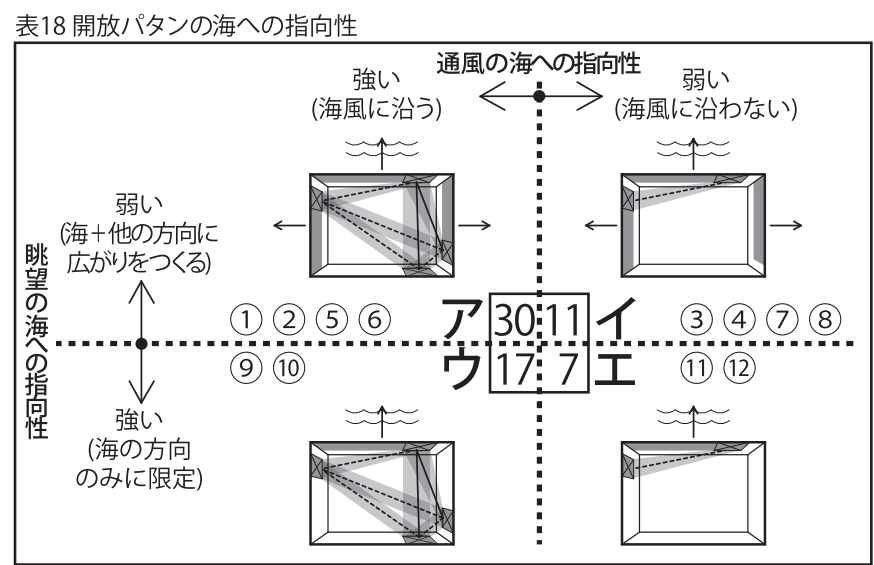




\section{2 開放パタンの海への指向性}

前節の開放パタンを、海への指向性から整理する（表 18）。眺望 は I が海に対して眺めを限定する指向性が強いもの、II と III は海を 基準に左右にも広がりをつくる指向性の弱いものとして大別できる。 一方、通風は海からの風向きに沿って風の経路を設ける $\mathrm{A} 、 \mathrm{~B}$ が海 への指向性が強いもの、C、D は海からの風向きとは無関係に風の 経路を設ける、指向性が弱いものと捉えることができる。このよう な指向性の組合せをみると、ア ( (1)(2)(5)(6) ) のように眺望・弱、通 風・強という指向性のタイプは、該当数が特に多い卓越した形式で あることがわかる。また、前面の大開口の開閉率に着目すると、眺 望・通風ともに海への指向性が強いウ（（9)(10)）のみに採風部を固定 部よりも多く設けるものが多い。これらア、ウの該当数が 7 割以上 $(47 / 65)$ を占める。このことから、海に臨む室の眺望と通風は、海 風に沿う通風の型を基本として、眺望に広がりをつくる場合は前面 の空を眺望優先の構成とし、眺望を海の方向一限定的に配する場合 は前面の空に採風の機能を重㸚合わせる傾向がわかる。

さらにこれらの構成的な特徵を視覚などの人の五感に対する開放 性といら観点から整理すると、開閉可能な空は 2 つ上を海寄りと 陸寄りに各々配置し、両者を離すことで、海からの風を室内にいな がら感じることができる居場所を設ける方法が主流である。そして、 これらの型は海側の眺望を拡張する場合は、側面の大開口に眺望と 通風を統合し、前面は視覚を優先して開放する空が主流である。こ れに対して、眺望を前面に限定する場合は、前面の大開口は通風を 主体とするものが多く、視覚以外の感覚に対しても海に開放する空 が主流であることがわかる。一方、通風の海一の指向性が弱いもの には、これらの海-陸という位置関係のなかでの空における眺望と 通風の使い分け、または重衫合わせのあり方を相対化するような特 徵的な例も見出された。No.39の例では、視覚にとどまらず五感に 対して開放する空をパノラマ状に展開し、前面および側面に向かっ て海を体感できる居場所が形成されている。それに対し、No.49の 例では、五感に対して開放する空が海側の前面のみに集中している ため、視覚的な正面性が強い居場所となっている。

\section{5. 結}

本研究では、現代日本の別荘における海に臨む室を対象に、海に 面寸る大開口の配置や風を取込むための空の開閉部分の組合せなど の構成的な特徵を考察することで、眺望と通風の関係性を検討した。 2 章では、海に臨む室を対象に、大開口の配置から眺望パタン を 3 つに分類した。さらに、前面の大開口について開閉率を検討し、 はめ殺しが主体の空とほぼ前面が開閉可能な窓が主流であることや、 居場所やその他の建築的要素との関係を捉え、天井高さの低いもの は大開口の配置により水平方向の広がりをつくるなど、眺望パタン の性格を考察した。

3 章では、採風部の組合せから通風について検討した。通風の経 路から 4 つのパタンに分類し、海風に沿うような経路をもつものが 多いことを明らかにした。さらに、通風領域が室に占める割合や居 場所との包含関係を併せて検討し、海軸以外に経路をもつものはそ の領域に広がりがあることや、その主領域に対する位置関係によっ て居場所の性格が分かれているなど、通風パタンの性格を考察した。 4 章では、前章までの結果をふまえ、眺望パタンと通風パタンの
関倸性を検討し 12 種の開放パタンを得た。また、海への指向性か ら開放性のパタンを整理することで、海に臨む別荘の開放性は、海 風に沿う通風の型を基本とし、眺望を海の方向へ限定的に配寸る場 合は前面の空に採風の機能を重祆合わせ、眺望に広がりをつくる場 合は前面の空を眺望優先の構成とする傾向があることを明らかにし た。

このように、海に臨むという特徴的な環境の下での現代日本の住 宅作品を対象に、空の配置や開閉の組合せといった建築空間を構成 する部位に内在する環境条件に対応する様々な方法から、眺望と通 風という異なる水準の開放のバランスによる屋外に開かれた住まい のあり方を検討した既往研究はみられず、現代日本の住宅設計にお ける空間と環境の関係性を把握する資料として有益であると考える。

注

注 1）参考文献1）の『別荘』という場所には、人びとが日常の喧噪を離れ、 自然豊かな中で思い思いの暮らしが楽しめる時間が流れています。」や参 考文献 2)の「その多くは自然を楽しむものとして、豊かな環境の中に置 かれます。建築家がその環境を建築にどのように取込み、その風土を読ん だのかがポイントとなるはずです。のように、自然を楽しむ住まいとし ての特徴が述べられている。

注 2)「新建築」、「新建築 住宅特集」「GA JAPAN」「GA HOUSES」誌の 1950 年 1 月〜 2014 年 6 月に掲載された日本国内の作品で、用途が別荘・週末 住宅・ゲストハウスのもので所在地がわかるもの (683 作品) のうち、本 研究で定義する海に臨む室をもつ、分析に十分な資料が得られた 65 事例 (63 作品) を対象とする。複数棟で構成される場合は各棟を 1 事例として 扱う。

注 3）空を介して室内から海をみることが可能だと判断できるリビングなど の共用空間。建具や幅員 $2 \mathrm{~m}$ 未満の通路によって接続される部分は含まな い。複数ある場合は面積の大きい室を対象とする。

注 4) 海に対する眺望はすべての事例でみられたが、前面以外の方向は地形 などの条件がさまざまであり、これらの方向は前面に比べ副次的と考光、 検討を行った。1. $8 \mathrm{~m}$ 以上の辺をもつ一連のガラス空を指し、ただし、短 辺が $0.5 \mathrm{~m}$ 未満のスリット状のものは除いた。

注 5）食卓やソファでローテーブルを囲むもののような複数の座で机を囲む ものは一つと捉える。

注 6) 家具の中心。ただし、複数ある場合は種類はソファ、位置は海に近い ものを優先する。

注 7) 居間の一般的な大きさである 4 間角 $(7.2 \mathrm{~m}$ 四方) の正方形の中心から の距離を参照した。

注 8) 高さ $\mathrm{h}=1,100 \mathrm{~mm}$ において $120^{\circ}$ の視野角におさまる範囲。

注 9）最高と最低の平均とする。ロフトのように吹抜けでつながる部分があ る場合はその上部の天井を含む。

注 10）本研究では、資料中の「庭」や「デッキ」などの図面表記における名 称によらず、直接出られる屋外空間をテラスと総称している。

注 11）参考文献 15）のP. 173 に「通風経路は開口の形状, 位置, 大きさ, 家 具などの配置によって大きく影響され」とある。

注 12）参考文献 16）の p. 83 に「人の居住する高さ (床上 $1.2 \mathrm{~m}$ 程度) に風が 行き渡るようにするのが望ましい」とあり、本研究では眺望と通風の重衩 合わせを検討するため、通風も眺望と同じ高さ $\mathrm{h}=1,100 \mathrm{~mm}$ で検討すること とした。

\section{参考文献}

1）特集 別荘 その場所の風景と魅力を知る，新建築住宅特集 2009 年 1 月 号, p. 83, 新建築社, 2009.1

2) 特集 別荘 景色と風土の受け止め方, 新建築住宅特集 2014 年 9 月号, p. 18, 新建築社, 2014.9

3）大垣直明，谷口尚弘：北海道における『居間中心型』プランの発展過程 に関する研究防寒技術の発展との関係を中心として, 日本建築学会計 画系論文集，第 590 号，pp. 131-136，2005.04

4）田上健一, 小倉暢之, 福島駿介：住要求及び居住実態からみたピロティ 型戸建住宅の空間特性, 日本建築学会計画系論文集, 第 522 号, pp. 147153, 1999. 8 
5）藤原紀沙，村田涼，湯淺和博，安田幸一：北海道の現代住宅における 主空間の形状と温熱環境の関係性, 日本建築学会計画系論文集，第 708 号, pp. 315-322, 2015.2

6) 村田涼, 金子明日美：現代日本のコートハウスにおける中庭まわりの断 面構成と冬期の光環境, 日本建築学会計画系論文集, 第 700 号, pp. 13211327, 2014. 6

7）金野千恵，塚本由晴：日照からみた住宅作品におけるロッジア的空間の 性格，日本建築学会計画系論文集，第644 号，pp. 2289-2296，2009.10

8）小泉隆，鈴木信宏：建築空間における空間秩序的太陽光効果とそれらの 要因, 日本建築学会計画系論文集, 第 516 号, pp. 153-160, 1999.2

9）野中俊宏, 倉㴊隆, 大場正昭, 遠藤智行, 後藤伴延, 塚本健二：密集 住宅地における建物表面風圧分布及び自然通風量に関する風洞実験：密集 住宅地における効果的な通風利用を目的とした開口部配置計画手法に関す る研究, 第 1 報, 日本建築学会環境系論文集, 第 642 号, pp. 951-956, 2009. 8

10）西澤繁毅，澤地孝男，丸田榮蔵，瀬戸裕直：住宅の密集度が風圧係数 および通風量に及ぼす影響の検討, 空気調和・衛生工学会大会学術講演 会論文集 平成 19 年 (3), pp. 1889-1892, 2007.8

11）綿貫安伸，秋元孝之，木村文雄，芥川郁雄：重層縁側を有寸る環境共 生住宅の夏期通風効果に関する研究, 日本建築学会技術報告集, 第 18 巻 ，第 39 号，pp. 607-612，2012.6

12）田沢文朗，絵内正道，久保田克己：排気塔を有する半地下室付住宅の 熱環境実測結果：夏の通風特性及び冬の燃料消費量実績について, 日本 建築学会北海道支部研究報告集 計画系，第 59 号，pp. 89-92，1986.3

13）赤林伸一，佐々木淑貴，坂口淳，富永禎秀：通風性能の定量的評価 手法に関する研究, 日本建築学会環境系論文集, 第 568 号, pp. 49-56, 2003. 6

14）塚本健二, 大場正昭, 倉㴊隆, 後藤伴延, 遠藤智行, 赤嶺嘉彦, 野 中俊宏：多数室換気に局所相似モデルを適用した場合の通風量予測の精 度検証及び戸建住宅の通風量解析への適用：通風時の換気量予測法に関す る研究, 第 4 報, 日本建築学会環境系論文集, 第 684 号, pp. 157-163, 2013.2

15）田中俊六, 武田仁, 土屋喬雄, 岩田利枝, 寺尾道仁：最新 建築環境 工学 [改訂 3 版］，株式会社井上書院，2006.3

16）山田由紀子：建築環境工学，株式会社培風館，1989.3

17) 板本守正, 市川裕通, 塘直樹, 片山忠久, 小林信行：学生のための建 築学シリーズ 環境工学 [四訂版]，株式会社朝倉書店，2002.3

18) Reyner Banham: Architecture of the Well-tempered Environment, Chicago University Press, 1969.

19）建築大辞典，第 2 版，彰国社，1993.6 


\title{
UTILIZATION OF SEAWARD VIEWS AND CROSS VENTILATION \\ IN CONTEMPORARY JAPANESE VILLAS
}

\author{
Kisa FUJIWARA*, Fuki SATO **, Ryo MURATA***, \\ Kazuhiro YUASA ${ }^{* * * *}$ and Koichi YASUDA ${ }^{* * * * *}$ \\ ${ }^{*}$ Grad. Stud., Tokyo Institute of Technology, M.Eng. \\ ** Former Grad. Stud., Tokyo Institute of Technology, M.Eng. \\ *** Assoc. Prof., Dept. of Architecture, Tokyo Institute of Technology, Dr.Eng \\ *** Assoc. Prof., Dept. of Architecture, Tokyo Institute of Technology, Dr.Eng. \\ ****** Prof., Dept. of Architecture, Tokyo Institute of Technology, Ph.D.
}

\section{Introduction:}

Each region has its own way of achieving comfortable environment. Japanese traditional houses have been designed to be open and passive for the summer. Seaside villas are characterized as dwellings in nature with magnificent views and fresh wind. In such villas, you can see various combinations of window constitution: a window facing the sea with the role of taking both views and wind, and windows with different roles like a seaward window for taking views and a landward window for taking wind.

Focusing on the constitution and placement of such windows would clarify the balance of different patency by views and cross ventilation. This study aims to clarify how to utilize seaward views and cross ventilation in contemporary Japanese seaside villas, focusing on morphological characteristic of the windows.

\section{Methods:}

First, views were examined. Views being classified by the placement of glazing in a room facing the sea, the area of the glazing facing the sea as well as the rate of patency was examined. Then, for furnished rooms, the number and kinds of the furniture, the distance to the seaside front of the villa, and views seen from the place where the occupants gather, were examined. Based on these results, the characteristics of view patterns by the placement of glazing were discussed.

Second, cross ventilation was examined. The positional relation among the windows taking wind and the relation between the windows and sea breeze were examined. To catch cross ventilation path regarding the place, the rate of the area with cross ventilation as well as the inclusion relation of the place where the residents gather, was discussed. Furthermore, the characteristics of cross ventilation were discussed.

Third, based on all these results, we discussed the patency by the combination of view patterns and cross ventilation patterns and sorted the patency patterns by the index of the directivity to the sea.

Results:

1) For rooms facing the sea, view patterns were classified into three. Through the investigation of the patency of glazing of the seaward side, we have demonstrated the characteristics of view patterns: Fixed windows and windows that are capable of opening and closing on the seaward side were main streams. Catching the relationship between places in which people gather in a villa and other architectural elements, we discussed the characteristics of view patterns.

2) By the combination of places taking wind, cross ventilation was examined morphologically. Cross ventilation was classified into four by its path. We have demonstrated that the path following the sea breeze was often found. Furthermore, through the investigation area occupying the room as well as the inclusion characteristics of peoples gathering places, the characteristics of cross ventilation patterns were discussed.

3) Forming a matrix that sets view patterns in a vertical line and cross ventilation in a horizontal line, we obtained twelve patterns of patency. Arranging the patency patterns from the directivity, we clarified the followings: the basic pattern is cross ventilation following sea breeze: when views are limited to the seaward side, windows on the seaward side are for taking both views and wind: when windows play the role of more expansive views, the views of windows on the seaward side tend to have priority over wind.

Conclusions:

The present study has demonstrated twelve patency patterns of the utilization of seaward views and cross ventilation in contemporary Japanese seaside villas. Furthermore, we clarified the characteristics of the window compositions by arranging the patterns from the directivity to the sea. 